\title{
Application of remote sensing and GIS for detection of long-term mangrove shoreline changes in Mui Ca Mau, Vietnam
}

\author{
V. Tran Thi ${ }^{1,2,3}$, A. Tien Thi Xuan ${ }^{3}$, H. Phan Nguyen ${ }^{4}$, F. Dahdouh-Guebas ${ }^{1,2,{ }^{*}}$, and N. Koedam ${ }^{1, *}$ \\ ${ }^{1}$ Laboratory of Plant Biology and Nature Management, Vrije Universiteit Brussel - VUB, Brussels, Belgium \\ ${ }^{2}$ Laboratory of Systems Ecology and Resource Management, Université Libre de Bruxelles - ULB, Brussels, Belgium \\ ${ }^{3}$ Center for HydroMet and Environment Consultancy, Institute of Meteorology, Hydrology and Environment - IMHEN, \\ Hanoi, Vietnam \\ ${ }^{4}$ Mangrove Ecosystem Research Centre, Hanoi National University of Education - HNUE, Hanoi, Vietnam \\ *These authors contributed equally to this work. \\ Correspondence to: V. Tran Thi (ttran1@vub.ac.be)
}

Received: 11 October 2013 - Published in Biogeosciences Discuss.: 20 December 2013

Revised: 22 May 2014 - Accepted: 22 May 2014 - Published: 21 July 2014

\begin{abstract}
Mui Ca Mau at the southern tip of Vietnam supports a large area of mangroves and has a high value for biodiversity and scenic beauty. This area is affected by erosion along the East Sea and accretion along the Gulf of Thailand, leading to the loss of huge stretches of mangroves along the East Sea and, in some cases, loss of environmental and ecosystem services provided by mangroves. In this study, we used remotely sensed aerial (1953), Landsat (1979, 1988 and 2000) and SPOT (1992, 1995, 2004, 2008, 2009 and 2011) images and the Digital Shoreline Analysis System (DSAS) to quantify the rate of mangrove shoreline change for a $58 \mathrm{yr}$ period. There were 1129 transects sampled at $100 \mathrm{~m}$ intervals along the mangrove shoreline and two statistical methods, namely end point rate (EPR) and linear regression rate (LRR), were used to calculate the rate of change of mangrove shorelines and distance from 1953 to 2011. The study confirms that erosion and accretion, respectively, are significant at the East Sea and Gulf of Thailand sides of Mui Ca Mau. The East Sea side had a mean erosion LRR of $33.24 \mathrm{~m} \mathrm{yr}^{-1}$. The accretion trend at the Gulf of Thailand side had an average rate of $40.65 \mathrm{~m} \mathrm{yr}^{-1}$. The results are important in predicting changes of coastal ecosystem boundaries and enable advanced planning for specific sections of coastline, to minimize or neutralize losses, to inform provincial rehabilitation efforts and reduce threats to coastal development and human safety.
\end{abstract}

\section{Introduction}

Mangrove ecosystems occur in the transitional zone between marine and terrestrial environments. Mangrove morphology and sedimentation are good indicators of interactions between relative sea level changes, coastal processes and sediment supply (Souza Filho et al., 2006; Gilman et al., 2007; McIvor et al., 2013). As emphasized by Souza Filho et al. (2006), a mangrove shoreline is one of the best geoindicators in global coastal change research.

Remote sensing and geographical information system (GIS) techniques have been used widely to assess changes in coastal shorelines (Chen and Rau, 1998; Ghosh et al., 2001; Lin et al., 2001; Van der Wal et al., 2002; Ali, 2003; Vanderstraete et al., 2006; Genz et al., 2007; Maiti and Bhattacharya, 2009; Sesli et al., 2009; Rebelo et al., 2009; Kuleli, 2010; Kuleli et al., 2011; and Hai-Hoa et al., 2013) and the boundaries of mangrove forests and other habitats over time (Woodroffe, 1995; Solomon et al., 1997; El-Raey et al., 1999; Wilton and Saintilan, 2000; Saintilan and Wilton, 2001; Cohen and Lara, 2003; Dahdouh-Guebas et al., 2004; Fromard et al., 2004; Souza Filho et al., 2006; Gilman et al., 2007; Satyanarayana et al., 2011; Giri et al., 2011; Heumann, 2011; and Nfotabong-Atheull et al., 2013). The Digital Shoreline Analysis System (DSAS) is an extension to ArcMap and was introduced to automatically or manually generate measurements of transects and metadata based on user-specified parameters, calculating rates of shoreline 
Table 1. History of universal DSAS application.

\begin{tabular}{|c|c|c|c|c|}
\hline No. & Purpose of DSAS application & Country & Period & References \\
\hline 1 & $\begin{array}{l}\text { Estimating rates of change of mangrove seaward edges and landward margins in Douala } \\
\text { Estuary }\end{array}$ & Cameroon & $1975-2007$ & Ellison and Zouh (2012) \\
\hline 2 & Calculating shoreline change rates in Accra & Ghana & 1904-2002 & Appeaning Addo et al. (2008) \\
\hline 3 & $\begin{array}{l}\text { Finding out the change rate of shoreline along the coast of Bhitarkanika Wildlife Sanc- } \\
\text { tuary, Orissa }\end{array}$ & India & 1973-2009 & Chand and Acharya (2010) \\
\hline 4 & Analysing shoreline changes along the coast between Kanyakumari and Tuticorin & India & 1999-2009 & Sheik and Chandrasekar (2011) \\
\hline 5 & Analysing shoreline change of Vedaranyam coast, Tamil Nadu & India & 1930-2005 & Natesan et al. (2013) \\
\hline 6 & $\begin{array}{l}\text { Consistently estimating the spatio-temporal dynamics of erosion and accretion of the } \\
\text { Sundarbans coastline }\end{array}$ & $\begin{array}{l}\text { India and } \\
\text { Bangladesh }\end{array}$ & 1973-2010 & Rahman et al. (2011) \\
\hline 7 & $\begin{array}{l}\text { Detecting the shorelines of the Sele Plain coastline between the towns of Salerno and } \\
\text { Agropoli and defining its change }\end{array}$ & Italy & 1870-2009 & Alberico et al. (2011) \\
\hline 8 & Quantitatively analysing shoreline changes on the Mediterranean coast in Turkey & Turkey & $1972-2002$ & Kuleli (2010) \\
\hline 9 & Detecting shoreline change on coastal Ramsar wetlands of Turkey & Turkey & 1972-2009 & Kuleli et al. (2011) \\
\hline 10 & Quantifying shoreline changes along the Sefton Coast & UK & 1955-2005 & Esteves et al. (2009) \\
\hline 11 & Mapping shoreline change in Puerto Rico & USA & $36 \mathrm{yr}$ & Thieler and Danforth (1994) \\
\hline 12 & $\begin{array}{l}\text { Analysing historical shoreline changes and associated coastal land loss along the US } \\
\text { Gulf of Mexico }\end{array}$ & USA & $1800 s-2002$ & Morton et al. (2004) \\
\hline 13 & $\begin{array}{l}\text { Analysing shoreline changes and associated coastal land loss along the US southeast } \\
\text { Atlantic coast }\end{array}$ & USA & $1800 s-2000$ & Morton and Miller (2005) \\
\hline 14 & $\begin{array}{l}\text { Analysing historical shoreline change and associated coastal land loss along sandy } \\
\text { shorelines of the California coast }\end{array}$ & USA & $1800 s-2002$ & Hapke et al. (2006) \\
\hline 15 & Analysing shoreline change at Mad Island Marsh Preserve, Matagorda County, Texas & USA & $1995-2005$ & Mangham and Williams (2007) \\
\hline 16 & Rates and trends of coastal change in California & USA & $1800 s-2001$ & Hapke et al. (2009) \\
\hline 17 & Estimating historical coastal cliff retreat along the California coast & USA & 1920-2002 & Hapke and Reid (2007) \\
\hline 18 & Analysing estuarine shoreline change: a case study of Cedar Island, North Carolina & USA & $1958-1998$ & Lisa et al. (2010) \\
\hline 19 & Analysing historical shoreline change along the New England and mid-Atlantic coasts & USA & $1800 \mathrm{~s}-2000 \mathrm{~s}$ & Hapke et al. (2010) \\
\hline 20 & Determining shoreline change along sheltered coastlines in Neuse River estuary & USA & $1958-1998$ & Cowart et al. (2011) \\
\hline 21 & Calculating shoreline change in Phan Thiet coastal area & Vietnam & 1973-2002 & Thao et al. (2008) \\
\hline 22 & $\begin{array}{l}\text { Examining the rates of change in width and the associated changes in adjacent shoreline } \\
\text { land use on Kien Giang coast, Vietnam }\end{array}$ & Vietnam & $2003-2009$ & Hai-Hoa et al. (2013) \\
\hline
\end{tabular}

changes and to provide other statistical information (Thieler et al., 2009). It utilizes the Avenue code to develop transects and rates, and the Avenue programming environment to automate and customize the user interface (Morton et al., 2004). The DSAS has been used widely to calculate the rate of shoreline changes (Table 1).

By 2012, Ca Mau Province had about 69000 ha of mangroves accounting for about $49.6 \%$ of the whole country (139046 ha) (MARD, 2013; Ca Mau Portal, 2014). Natural and anthropogenic factors in the mangroves around Mui $\mathrm{Ca}$ Mau have caused erosion along the East Sea coast and accretion along the Gulf of Thailand shoreline. As stated by the MAB Vietnam (2008), these changes have led to the loss of huge stretches of mangroves along East Sea resulting in the decrease and, in some cases, loss of mangrove environmental and ecosystem services. The effects include loss of spawning grounds for aquatic species and the loss of the wave buffering and sheltering effect of mangroves, threatening residential areas and infrastructure behind the mangrove (MAB Vietnam, 2008). In addition, by the end of the 21 st century, average sea level in the study area is projected to rise $59-75 \mathrm{~cm}$ and $62-$ $82 \mathrm{~cm}$ along the East Sea and the Gulf of Thailand, respectively (MONRE, 2012). However the change in the mangrove shoreline due to accretion and erosion at Mui Ca Mau has not been quantified but merely observed. Key weaknesses in previous attempts at government mangrove rehabilitation have been uniform application of homogeneous monoculture plantations with little consideration for maintenance needs or coastal dynamics, which dictate suitability of mangrove rehabilitation at any given site (IUCN, 2012). It is, therefore, very important to detect quantitatively the changes of mangrove shoreline. This will be used effectively to predict the changes of coastal ecosystem boundaries and enable advanced planning for specific sections of coastline, to minimize or neutralize losses, to inform provincial rehabilitation efforts and reduce threats to coastal development and human safety (Dahdouh-Guebas, 2002; Gilman et al., 2007; IUCN, 2012).

In this research, we quantify the rate of mangrove shoreline change around Mui Ca Mau with remotely sensed images of aerial photographs, Landsat and SPOT data for a $58 \mathrm{yr}$ period and applying DSAS.

\section{Materials and methods}

\subsection{Study area}

The study area is located at the southernmost point of $\mathrm{Ca}$ Mau Province between latitude $8^{\circ} 32^{\prime}-8^{\circ} 49^{\prime} \mathrm{N}$ and longitude $104^{\circ} 40^{\prime}-105^{\circ} 19^{\prime}$ E (Fig. 1). It covers entirely Ngoc Hien District and partly Nam Can District of Ca Mau Province. We chose this area because it is a lowland deltaic plain $(0-3 \mathrm{~m}$ 


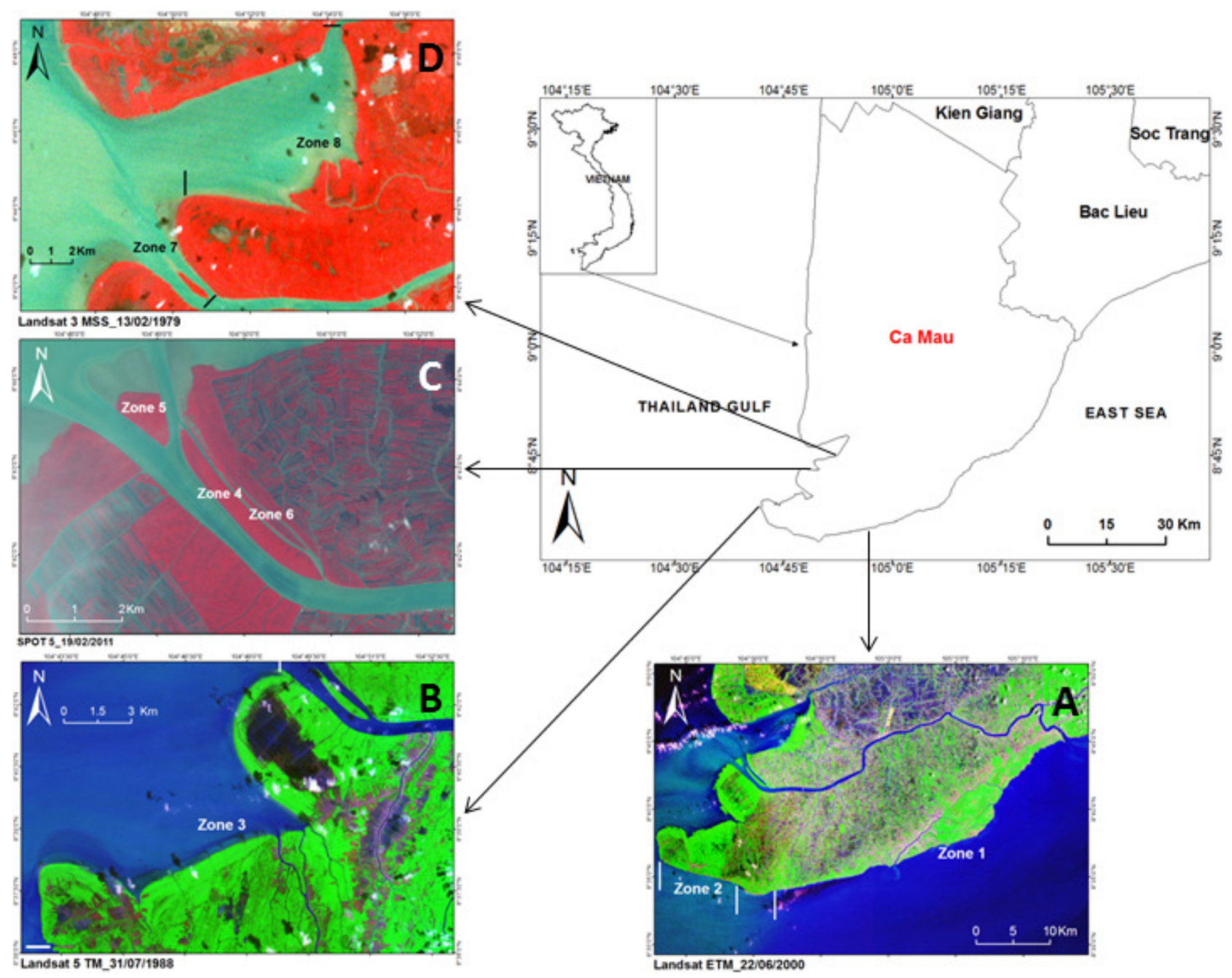

Figure 1. Map of the study area. It is divided into eight zones that depend on coastal characteristics and availability of remotely sensed data. (A) zones 1 and 2; (B) zone 3; (C) zones 4, 5 and 6; and (D) zones 7 and 8.

above mean sea level) and strongly divided by a system of natural rivers and a dense network of canals (Hong and San, 1993). The water flow regime in the area is under the influence of both the East Sea and the Gulf of Thailand with the eastern flow the stronger. The whole area is characterized by a soft muddy soil and influenced by semidiurnal tides originating from the East Sea (tidal amplitude $2-3 \mathrm{~m}$ ) and by the diurnal tides from the Gulf of Thailand (tidal amplitude 0.5-0.8 m) (Hong and San, 1993). More importantly, Ca Mau supports the most substantial area of mangroves (Hong and San, 1993), and it is a natural mangrove ecosystem with a high conservation value for its biodiversity and scenic beauty (MAB Vietnam, 2008). There are 27 true mangrove species in Ca Mau, with Avicennia alba Blume, Avicennia marina (Forssk.) Vierh., Avicennia officinalis L., Rhizophora apiculata Bl., Bruguiera parviflora Wight \& Arnold ex Griffith, Ceriops zippeliana Blume and Nypa fruticans (Thunb.) Wurmb. amongst the major species (Hung and Tan, 1999;
Massó i Alemán et al., 2010). But natural and anthropogenic factors in the mangroves around Mui Ca Mau have caused erosion along the East Sea and accretion along the Gulf of Thailand.

Our study area extended from Bo De river mouth on the east coast to Bay Hap Estuary on the west coast of Mui Ca Mau. Based on coastal characteristics (erosion and accretion) and availability of remotely sensed data, this area was divided into eight zones for the purpose of the study (Fig. 1 and Table 2).

\subsection{Data sources and geo-referencing}

Aerial photographs from 1953 and remotely sensed image data of Landsat (1979, 1988, and 2000) and SPOT (1992, 1995, 2004, 2008 and 2009, and 2011) images were used to analyse the change rate of mangrove shorelines over $58 \mathrm{yr}$ (specifications of remotely sensed data used in this study are 
Table 2. Eight zones in the study area divided basing on coastal characteristics and availability of remotely sensed data.

\begin{tabular}{|c|c|c|c|c|c|}
\hline Zone & $\begin{array}{l}\text { Length } \\
(\mathrm{km})\end{array}$ & Direction & $\begin{array}{l}\text { Description } \\
\text { position }\end{array}$ & $\begin{array}{l}\text { Accretion/ } \\
\text { erosion }\end{array}$ & $\begin{array}{l}\text { Time } \\
\text { series }\end{array}$ \\
\hline 1 & 49.0 & Northeast & $\begin{array}{l}\text { From Bo De river mouth to } \mathrm{O} \\
\text { Ro river mouth }\end{array}$ & High erosion & $\begin{array}{l}\text { 1953, 1979, 1988, 1992, 1995, } \\
2000,2004,2008,2011\end{array}$ \\
\hline 2 & 11.1 & Southeast & $\begin{array}{l}\text { From Vam Xoay to Rach Tau } \\
\text { river mouth }\end{array}$ & Erosion & $\begin{array}{l}\text { 1953, 1979, 1988, 1992, 1995, } \\
\text { 2000, 2004, 2009, } 2011\end{array}$ \\
\hline 3 & 22.0 & Southwest & $\begin{array}{l}\text { From Hai Thien canal to Cua } \\
\text { Lon Estuary }\end{array}$ & Accretion & $\begin{array}{l}\text { 1953, 1979, 1988, 1992, 1995, } \\
\text { 2000, 2004, 2009, } 2011\end{array}$ \\
\hline 4 & 7.5 & West & $\begin{array}{l}\text { Con Trong island, formed in } \\
1960 \text { s, at Cua Lon Estuary }\end{array}$ & Accretion & $\begin{array}{l}\text { 1979, 1988, 1992, 1995, 2000, } \\
\text { 2004, 2009, } 2011\end{array}$ \\
\hline 5 & 1.7 & West & $\begin{array}{l}\text { Con Ngoai island, formed in } \\
\text { 1980s, at Cua Lon Estuary }\end{array}$ & Accretion & $\begin{array}{l}\text { 1992, 1995, 2000, 2004, 2009, } \\
2011\end{array}$ \\
\hline 6 & 4.5 & West & $\begin{array}{l}\text { Con Moi island, newly } \\
\text { formed in 2000s, at Cua Lon } \\
\text { Estuary }\end{array}$ & $\begin{array}{l}\text { Accretion } \\
\text { and erosion }\end{array}$ & 2009,2011 \\
\hline 7 & 6.3 & West & $\begin{array}{l}\text { On right bank of Cua } \\
\text { Lon river }\end{array}$ & Accretion & $\begin{array}{l}\text { 1953, 1979, 1988, 1992, 1995, } \\
2000,2004,2009,2011\end{array}$ \\
\hline 8 & 11.8 & Northwest & $\begin{array}{l}\text { From Cua Lon to Bay Hap es- } \\
\text { tuaries }\end{array}$ & Accretion & $\begin{array}{l}1979,1988,1992,2000,2004, \\
2011\end{array}$ \\
\hline
\end{tabular}

Table 3. Specifications of image data.

\begin{tabular}{llllcl}
\hline No. & Name & Path/row & Acquisition date & Resolution $(\mathrm{m})$ & Study area \\
\hline 1 & Aerial photos & & 1 Jan 1953 & 20 & $1,2,3,7$ \\
2 & Landsat 3 MSS & $135 / 054$ & 13 Feb 1979 & 79 & $1,2,3,4,7,8$ \\
3 & Landsat 5 TM & 125 and 126/054 & 31 Jul 1988 & 30 & $1,2,3,4,7,8$ \\
4 & Landsat ETM & 125 and 126/054 & 22 Jun 2000 & 30 & $1,2,3,4,5,7,8$ \\
5 & SPOT 2 & $273 / 332$ & 3 Jan 1992 & 20 & $1,2,3,4,5,7,8$ \\
& SPOT 2 & $273 / 333$ & 3 Jan 1992 & 20 & \\
& SPOT 2 & $274 / 333$ & 3 Jan 1992 & 20 & \\
6 & SPOT 2 & $273 / 333$ & 12 Dec 1995 & 20 & $1,2,3,4,5,7$ \\
& SPOT 2 & $274 / 333$ & 12 Dec 1995 & 20 & \\
7 & SPOT 5 & $273 / 332$ & 7 Jan 2004 & 10 & $1,2,3,4,5,7,8$ \\
& SPOT 5 & $273 / 333$ & 7 Jan 2004 & 10 & \\
& SPOT 5 & $274 / 333$ & 7 Jan 2004 & 10 & \\
8 & SPOT 4 & $274 / 333$ & 8 Sep 2008 & 10 & 1 \\
9 & SPOT 2 & $273 / 333$ & 19 Jan 2009 & 20 & $2,3,4,5,6,7$ \\
10 & SPOT 5 & $273 / 332$ & 19 Feb 2011 & 10 & $1,2,3,4,5,6,7,8$ \\
& SPOT 5 & $273 / 333$ & 19 Feb 2011 & 10 & \\
& SPOT 5 & $274 / 333$ & 19 Feb 2011 & 10 & \\
\hline
\end{tabular}

given in Table 3). The Landsat images were freely downloaded from the US Geological Survey (USGS) at level 1T which has been processed to standard terrain correction. Other images were purchased by the Laboratory of Plant Biology and Nature Management, Vrije Universiteit Brussel and the Institute of Meteorology, Hydrology and Environment. The SPOT images were processed at the level of orthorectified using ground control points and a digital elevation model. All these data were geo-referenced to the UTM
WGS-1984 Zone 48N projection and coordinate system with further geometric correction using ENVI.

\subsection{Mangrove shoreline digitization and detection}

The mangrove forest edge was used as the shoreline indicator to derive historical rates of mangrove shoreline change in the study area. For the eroding east side, mangrove trees occur as far seaward as there is soil to remain stable, with no mudflats 
beyond them. For the accreting west side, the first occurrence of a closed mangrove canopy was used as a border. Long intertidal mudflats extend beyond the mangrove vegetation in these areas, but they are not yet suitable for mangrove propagules to establish as the water depth over time is still too high. Using the closed canopy mangrove forests as border of the land area is an acceptable solution to distinguish the mudflats from the land area, although single mangrove individuals and young plants colonizing the newest areas are excluded from the analysis. ArcGIS was used to manually digitize the mangrove shoreline position in 1953.

Normalized Difference Vegetation Index (NDVI) is one of the most successful and widely used ways to simply and quickly identify vegetated areas by detecting living green plant canopies in multispectral remote sensing data (Seto and Fragkias, 2007; Vo et al., 2013). In this study, NDVI was used to distinguish vegetated areas from other surface types, especially for the purpose of this study between water or land and mangrove. In order to improve the accuracy of mangrove shoreline detection, the clustering threshold technique of Otsu (1979) was used. This detects an optimum threshold by minimizing weighted sum of within-class variances of the foreground and background pixels and gives satisfactory results when the numbers of pixels in each class are close to each other. The Otsu method remains one of the most cited threshold methods (Sezgin and Sankur, 2004; Kuleli, 2010; Kuleli et al., 2011). The border pixels between segmented vegetation/water or land regions can be delineated as mangrove shorelines. These are delineated using binary images produced from a threshold-based segmentation algorithm. As a result, images were divided into two major segments: mangrove and water or land. After this process, the boundaries of the classified regions were vectorized by using the raster to vector conversion application of ENVI. Next, the conversion accuracy was evaluated by overlaying the extracted mangrove shorelines with the original Landsat and SPOT images.

\subsection{Mangrove shoreline rate calculation}

Calculating mangrove shoreline movement and changes were formalized into DSAS version 4.2, an extension to ArcMap developed by the USGS. DSAS computes rate-ofchange statistics from multiple historic shoreline positions residing in a GIS (Thieler et al., 2009). DSAS generates transects that are cast perpendicular to the baseline at a userspecified spacing alongshore. The intersections of transects and the mangrove shorelines along this baseline are then used to calculate the rate-of-change statistics. In this study, a total of 1129 transects were regularly placed at a spacing of $100 \mathrm{~m}$ by applying DSAS software. To assess the spatial and temporal movement trend of mangrove shoreline positions, a hypothetical baseline was constructed offshore and parallel to the general orientation of the mangrove shoreline. The generated transects together with the extracted mangrove shorelines are graphically shown in Figs. 2-5.

In order to calculate erosion/accretion rates, many statistical methods have been applied, such as end point rate (EPR), average of rates (AOR), minimum description length (MDL), jackknifing (JK), linear regression rate (LRR), reweighted least squares (RLS), weighted least squares (WLS), reweighted weighted least squares (RWLS), least absolute deviation (LAD), and weighted least absolute deviation (WLAD) (Dolan et al., 1991; Thieler et al., 1995; Crowell et al., 1997; Coyne et al., 1999; Honeycutt et al., 2001; Genz et al., 2007; Kuleli, 2010; Kuleli et al., 2011; Sheik and Chandrasekar, 2011). The two most frequently cited methods are EPR and LRR. In this study, two comparative statistical methods of EPR and LRR were used to calculate the change in rates of mangrove shorelines in Mui Ca Mau. The EPR is simply the rate determined by the changes in position between the oldest and most recent shorelines in a given data set. As it only considers the earliest and the latest shoreline positions, it was suitable for the short-term mangrove shoreline change analysis of zone 6 (Con Moi) with only two mangrove shorelines of 2009 and 2011 available. The LRR is the result of estimating the average rate of change using a number of shoreline positions over time, with the change statistic of fitting a least-squared regression line to all shoreline points for each transect. The linear regression rate is the slope of the line. Therefore, LRR was used to analyse the long-term mangrove shoreline change (from 1953 to 2011) of the other study zones. In this study, data uncertainty was $\pm 5 \mathrm{~m}$, and confidence interval was $90 \%$ determined as a weighted linear rate parameter.

\subsection{Ground truth and social survey}

Field ground truth was carried out in 2006, 2007, 2010 and 2011. A total of $150 \mathrm{GPS}$ points collected in the field with attribute information on location of the seaward edge of the mangroves and households in and around the mangroves area. These points were imported to ArcGIS for analysis.

Social surveys in households close to the mangrove area were conducted using interviews. The target group was the population with experience of the region. In 1980s, there was unauthorized influx of people from other provinces migrated to Ngoc Hien District (Hong and San, 1993). Therefore, the people with ages ranging from 45 to $65 \mathrm{yr}$ old were chosen for the interviews. The major objectives regarded changes they had observed in the mangrove area over time. Collected information is used in the discussion.

\section{Results}

Table 4 summarizes rates of mangrove shoreline change as averages of the erosion or accretion values on generated transects in each zone, along with maximum and minimum 
Table 4. Change rate of mangrove shoreline in eight zones of the study area. For zone 6, there are only two mangrove shorelines of 2009 and 2011, no linear regression statistic was run, and hence end point rate is used. For the rest, mangrove shoreline change was derived from linear regression rates.

\begin{tabular}{|c|c|c|c|c|c|c|c|c|c|c|}
\hline \multirow[t]{2}{*}{ Items } & \multicolumn{10}{|l|}{ Zones } \\
\hline & 1 & 2 & 3 & $\begin{array}{l}4 \\
\mathrm{~A}\end{array}$ & B & 5 & $\begin{array}{l}6 \\
\mathrm{~A}\end{array}$ & B & 7 & 8 \\
\hline Number of transects & 489 & 108 & 219 & 72 & 2 & 16 & 22 & 22 & 62 & 117 \\
\hline Transect length (m) & 5500 & 1050 & $\begin{array}{l}1100 \\
2000 \\
5600 \\
3700 \\
2700\end{array}$ & $\begin{array}{l}300 \\
170\end{array}$ & 1900 & 500 & 90 & 90 & $\begin{array}{l}1900 \\
3700\end{array}$ & $\begin{array}{l}1800 \\
4500 \\
2000\end{array}$ \\
\hline $\begin{array}{l}\text { Mean of mangrove shoreline change } \\
\left(\mathrm{m} \mathrm{yr}^{-1}\right)\end{array}$ & $\begin{array}{l}-38.31 \\
\pm 14.26\end{array}$ & $\begin{array}{l}-10.28 \\
\pm 2.64\end{array}$ & $\begin{array}{l}+44.74 \\
\pm 24.36\end{array}$ & $\begin{array}{l}+1.31 \\
\pm 1.46\end{array}$ & $\begin{array}{l}+48.69 \\
\pm 3.01\end{array}$ & $\begin{array}{l}+7.38 \\
\pm 7.61\end{array}$ & $\begin{array}{l}+9.59 \\
\pm 6.99\end{array}$ & $\begin{array}{l}-5.80 \\
\pm 3.69\end{array}$ & $\begin{array}{l}+23.00 \\
\pm 11.26\end{array}$ & $\begin{array}{l}+65.00 \\
\pm 46.61\end{array}$ \\
\hline $\begin{array}{l}\text { Maximum of mangrove shoreline } \\
\text { change }\left(\mathrm{m} \mathrm{yr}^{-1}\right)\end{array}$ & -71.54 & -13.73 & 95.67 & 5.52 & 50.82 & 20.07 & 20.38 & 0.94 & 47.03 & 133.41 \\
\hline $\begin{array}{l}\text { Minimum mangrove shoreline change } \\
\left(\mathrm{m} \mathrm{yr}^{-1}\right)\end{array}$ & -12.61 & -2.54 & 1.14 & 0 & 46.56 & 0.25 & 1.16 & -11.17 & 6.40 & 0.62 \\
\hline
\end{tabular}

values. Positive EPR and LRR values represent mangrove shoreline movement towards the sea (accretion rate), and negative values indicate movement inland (erosion rate). Mangrove shoreline changes emphasize erosion along the East Sea and accretion along the Gulf of Thailand, as observed previously. It is also clear that the islands in the Cua Lon Estuary were recently formed.

Along the East Sea, mangrove shoreline of zone 1 is located between Bo De and O Ro river mouths. Over $49 \mathrm{~km}$, there were 489 transects used to intersect the base line and nine mangrove shorelines of 1953, 1979, 1988, 1992, 1995, 2000, 2004, 2008 and 2011 (Table 2 and Fig. 2). The rate of change varied from $-12.61 \mathrm{~m} \mathrm{yr}^{-1}$ to $-71.54 \mathrm{~m} \mathrm{yr}^{-1}$ with a mean rate of $-38.31 \pm 14.26 \mathrm{~m} \mathrm{yr}^{-1}$ (Table 4). The maximum erosion rate was near to Bo De river mouth, $-71.54 \mathrm{~m} \mathrm{yr}^{-1}$ (Fig. 2).

The mangrove shoreline of zone 2, from Vam Xoay to Rach Tau river mouth, recorded dominant erosion. Similar to zone 1 , nine mangrove shorelines were observed in zone 2 , but mangrove shoreline 2008 was replaced by the one in 2009 (Fig. 3). Along the $11.2 \mathrm{~km}, 111$ transects were generated (Table 4 and Fig. 3). Over the period 1953-2011, the change rate of the shorelines ranged from $-2.54 \mathrm{~m} \mathrm{yr}^{-1}$ to $-13.73 \mathrm{~m} \mathrm{yr}^{-1}$, with an average of $-10.28 \pm 2.64 \mathrm{~m} \mathrm{yr}^{-1}$ (Table 4).

On the other hand, mangrove accretion is significant along the Gulf of Thailand. A time series of nine mangrove shorelines was extracted. Along the $22 \mathrm{~km}$ of mangrove shoreline of zone 3 from Ca Mau tip (Hai Thien canal) to Cua Lon Estuary, the rate of accretion averaged over 219 transects was $44.74 \pm 24.36 \mathrm{~m} \mathrm{yr}^{-1}$. Maximum accretion rate in this zone was $95.67 \mathrm{~m} \mathrm{yr}^{-1}$ at transect between Nam Khoi and Ba Mang canals (Table 4 and Fig. 3).

Further, in the Cua Lon Estuary, three newly formed islands of Con Trong (zone 4), Con Ngoai (zone 5) and Con Moi (zone 6) continue to be accreted (Fig. 4). Con Trong Island (zone 4) was formed during the 1960s and is located in the middle of the estuary. Hence, there was no mangrove shoreline in 1953 to be observed (Fig. 4). A total of 74 transects were extracted in zone 4 (Table 4 and Fig. 4). Maximum accretion rate was observed at the northeastern tip of the island. Hence, zone 4 was divided into two subzones 4A and 4B. During 1979-2011, 72 transects of subzone 4A were evidenced average accretion rate of $1.31 \pm 1.46 \mathrm{~m} \mathrm{yr}^{-1}$ that was much lower than the two transects of subzone 4B $\left(48.69 \pm 3.01 \mathrm{~m} \mathrm{yr}^{-1}\right)$ (Table 4).

Located further offshore, Con Ngoai (zone 5) was formed during the 1980s. Hence, mangrove shorelines of 1953, 1979 and 1988 are not available. It is clearly seen that this island is expanding at the northeastern tip. For 16 transects there, the average accretion rate was $7.38 \pm 7.61 \mathrm{~m} \mathrm{yr}^{-1}$ over the period 1992-2011 (Table 4 and Fig. 4). For the other parts of the island, the mangrove shoreline was stable, and no change was observed (Fig. 4).

Con Moi (zone 6) is a newly formed island during the 2000s, and only two mangrove shorelines are available (2009 and 2011) for comparison (Fig. 4). The EPR was applied and showed accretion dominated the eastern bank of the island (subzone 6A), whereas erosion dominated the western bank (subzone 6B) (Table 4 and Fig. 4). Over the 22 transects of subzone $6 \mathrm{~A}$, the mean accretion rate was $9.59 \pm 6.99 \mathrm{~m} \mathrm{yr}^{-1}$. The mean erosion rate was $-5.80 \pm 3.69 \mathrm{~m} \mathrm{yr}^{-1}$ for the 22 transects of subzone $6 \mathrm{~B}$. 


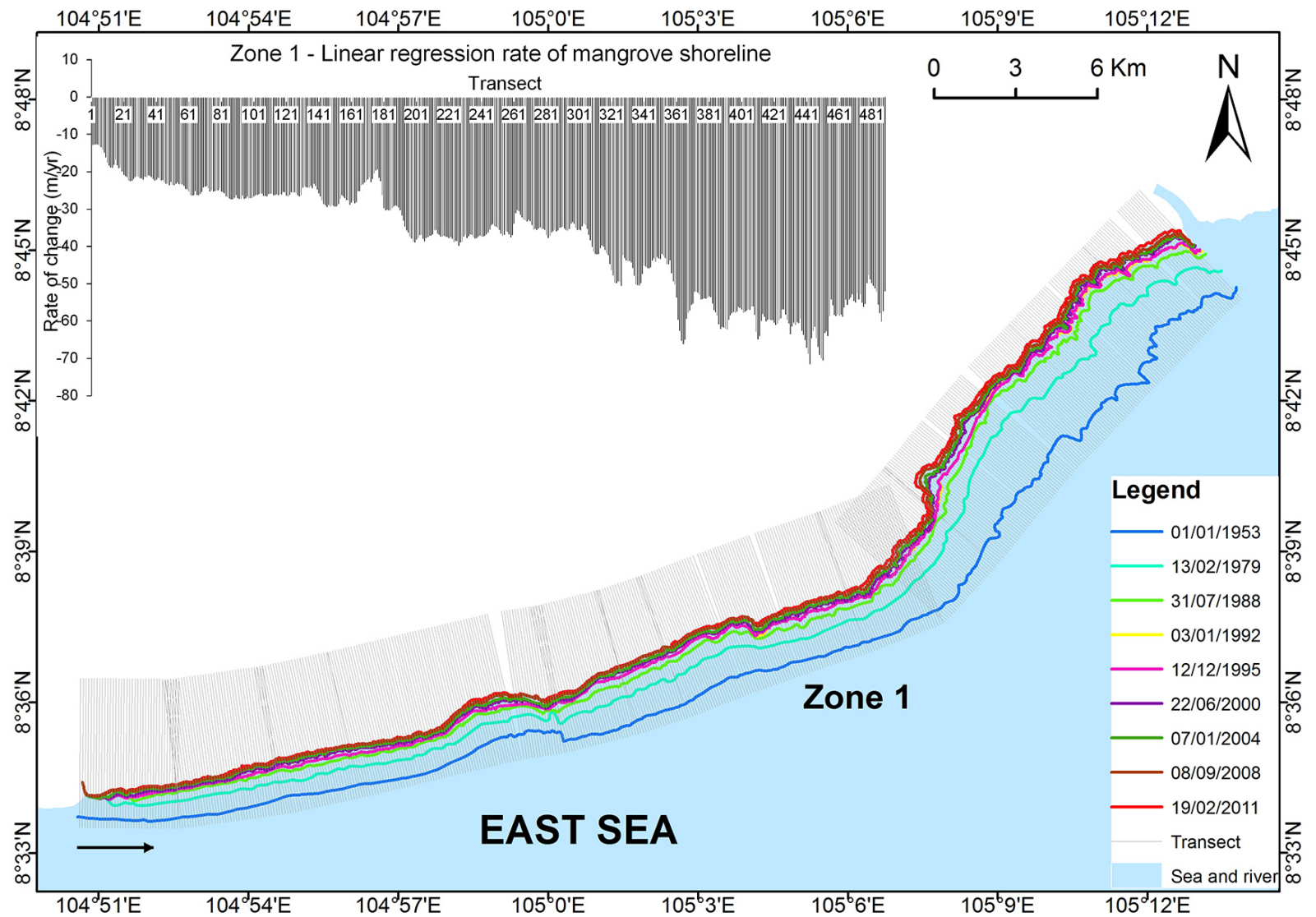

Figure 2. Mangrove shoreline changes in zone 1 which is located between Bo De and O Ro river mouths, along the East Sea. DSAS software generated 489 transects. The arrow shows the direction of transects from 1 to 489 which have a linear regression rate illustrated in the graph at the top left corner.

Located on the western bank of the Cua Lon River, zone 7 is also a sediment receiver. Over the period 1953-2011, nine mangrove shorelines were reported. There were 62 transects generated in zone 7 (Fig. 5). Change rate of mangrove shorelines ranged from $6.40 \mathrm{~m} \mathrm{yr}^{-1}$ to $47.03 \mathrm{~m} \mathrm{yr}^{-1}$ with mean accretion rate of $23.00 \pm 11.26 \mathrm{~m} \mathrm{yr}^{-1}$ (Table 4).

Next to zone 7, six mangrove shorelines of 1979, 1988, 1992, 2000, 2004, and 2011 were remained in zone 8. Over $11.8 \mathrm{~km}$ of zone 8,117 transects were recorded (Fig. 5). The mean accretion rate was $65.00 \pm 46.61 \mathrm{~m} \mathrm{yr}^{-1}$ (Table 4).

\section{Discussion}

\subsection{Erosion along the East Sea}

Analysis from a time series of mangrove shoreline along the East Sea shows average erosion rate varying from $10.28 \mathrm{~m} \mathrm{yr}^{-1}$ (zone 2) to $38.31 \mathrm{~m} \mathrm{yr}^{-1}$ (zone 1) (Table 4). In comparison to studies at other sites, these are much higher. In the Douala Estuary, Cameroon, results showed the seaward edge of mangroves had over two thirds of the shoreline experiencing dieback, at a rate of up to $3 \mathrm{~m} \mathrm{yr}^{-1}$ over the period 1975-2007 (Ellison and Zouh, 2012). Gilman et al. (2007) observed mean landward migration of American Samoa mangroves over 4 decades was from $6.39 \mathrm{~cm} \mathrm{yr}^{-1}$ to $3.27 \mathrm{~m} \mathrm{yr}^{-1}$. Recently, Hai-Hoa et al. (2013) found the width of fringe mangroves had been significantly reduced on Kien Giang coast, Vietnam, with average rates of width reduction from $3 \mathrm{~m} \mathrm{yr}^{-1}$ to $7 \mathrm{~m} \mathrm{yr}^{-1}$ over the period 2003-2009. The causes of the changes have been proposed to be reduction in sediment supply and mangrove overexploitation (Ellison and Zouh, 2012), shrimp farm expansion (Hai-Hoa et al., 2013) and climate change, especially sea level rise (Gilman et al., 2007).

Because of the specific history of the study area, it is very difficult to compare the mangroves in the study area to mangrove systems elsewhere (Koedam et al. 2007). This constitutes an added value to performing this research. Indeed, it is clear that the coast of Mui Ca Mau is strongly dynamic. Mangrove loss on the eastern side is arising primarily because of natural changes in the coastal system and the impact of the northeast monsoon, plus as a consequence of human activities such as herbicide application during the Vietnam War, deforestation, and the reduction of sediment supply from the 


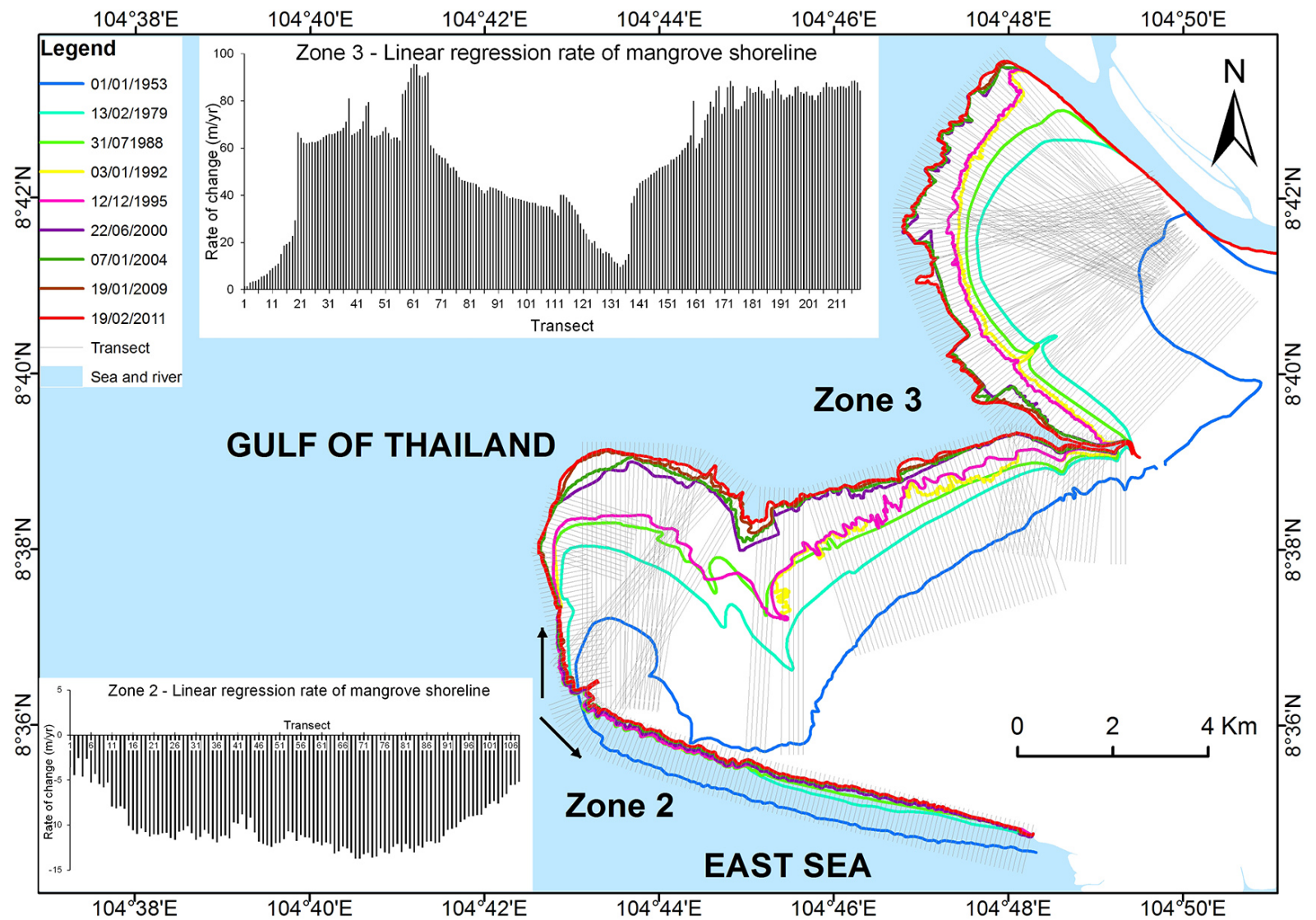

Figure 3. Mangrove shoreline change in zones 2 and 3. Zone 2 is located on the East Sea coast and zone 3 on the Gulf of Thailand. DSAS software generated 108 and 219 transects for zones 2 and 3, respectively. The arrow shows the direction of transects from 1 to 108 for zone 2 and from 1 to 219 for zone 3 .

Mekong mouths by the rapidly increasing number of dams on the Mekong system.

During the Vietnam War (1961-1971), herbicides were sprayed by the United States forces for military purposes at a rate more than an order of magnitude greater than for similar domestic weed control (Stellman et al., 2003). Mui Ca Mau was one of the two heavily sprayed regions in the south of Vietnam (Hong and San, 1993). Ross (1975) reported from 1966 to 1970 the tip of Ca Mau received $1027 \mathrm{~kg}$ of Agent Orange from 55 missions and $285 \mathrm{~kg}$ of Agent White. As a result, $52 \%$ of dense mangroves at the tip of $\mathrm{Ca}$ Mau were destroyed (Hong and San, 1993). In the study area, bare waste land area increased about 10 times from 2003 ha in 1953 to 21964 ha in 1975 (Van et al., 2014), with a similarity to the flight paths of spray missions delivering Agent Orange and Agent White during the war (Stellman et al., 2003). After this time, forests in the affected areas have consisted mainly of secondary growth, much of it scrubby, and plantations (FAO, 2007).

In Mui Ca Mau, Rhizophora sp. has value for timber and poles, firewood and charcoal (Hong and San, 1993). After the war, there was rapid population growth in the study area, which resulted in increased demands on the mature forests remaining in Ca Mau. Exploitation was indiscriminate despite regulation of the utilization of mangrove forests. From 1975 to 1983, there were $207798.4 \mathrm{~m}^{3}$ of timber, $686961.6 \mathrm{~m}^{3}$ of firewood, and 23030.19 tons of charcoal exploited from the mangrove forests of the former Minh Hai Province (Ca Mau and Bac Lieu provinces) (Hong and San, 1993). In addition, conversion to brackish water aquaculture is a major agent of mangrove change in Vietnam (Giesen et al., 2006). Extensive expansion of aquaculture in the 1980s and 1990s resulted in the loss of about two thirds of Vietnam's mangroves by 2000 (Hashimoto, 2001). At the initial stage, extensive tidal areas in $\mathrm{Ca}$ Mau were converted for agriculture. Although initially yields were high, crops eventually failed. The reclaimed land was rapidly converted to aquaculture (Hong and San, 1993; Binh et al., 2005). In 1980 s, most of forestry aquaculture enterprises in Ca Mau cleared mangrove forest for the expansion of shrimp farming area, and this lead to the further deterioration of mangrove forests (Hong and San, 1993).

Upstream hydrological engineering (hydroelectric dams and irrigation canals) contributes an additional layer of 


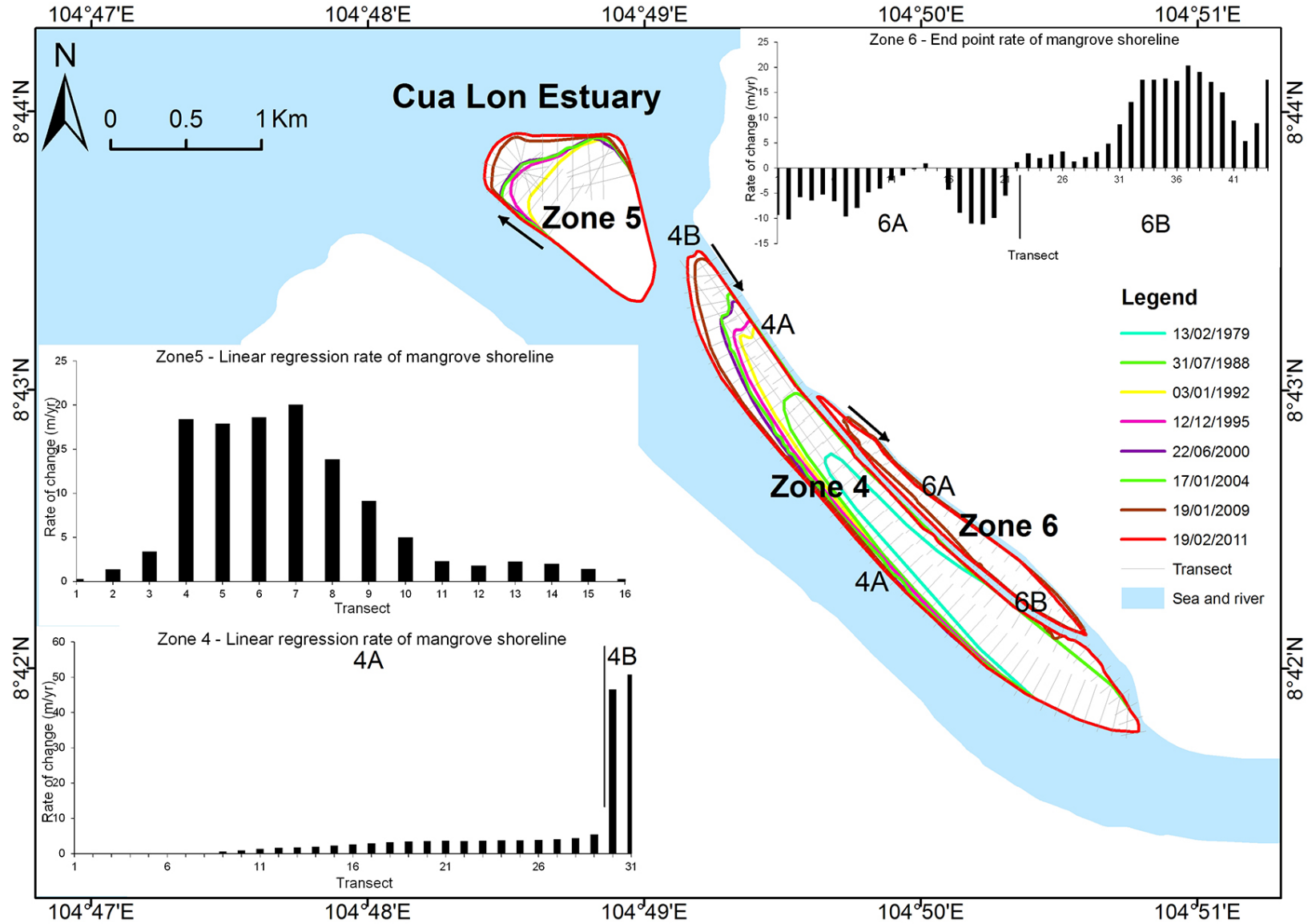

Figure 4. Mangrove shoreline change in zone 4 (Con Trong), zone 5 (Con Ngoai) and zone 6 (Con Moi) in the Cua Lon Estuary. These are new islands were formed in the 1960s, 1980s, and 2000s, respectively. Therefore, 8, 5 and only 2 mangrove shorelines were generated for zone 4, zone 5 and zone 6, respectively. DSAS software generated 74, 16 and 44 transects for zone 4, zone 5 and zone 6 , respectively. Zone 4 and zone 6 each is divided into two dynamic regions, A and B. The arrows show the direction of transects from 1 to 74 for zone 4 , from 1 to 16 for zone 5 and from 1 to 44 for zone 6 .

complexity by modifying local coastal dynamics, which can impact mangrove ecosystem permanence by altering rates of erosion or accretion (Hashimoto, 2001). Dam construction on rivers has been reported to reduce (Ellison and Zouh, 2012) or to increase (Dahdouh-Guebas et al., 2005; Koedam and Dahdouh-Guebas, 2008) the volume of water and riverine sediment supply to the sea and coastal mangroves in the affected and adjacent river basins resulting in altered mangrove extent and/or quality. The Mekong River is likely to already have lower sediment loads due to damming of the main stream and tributaries, and this will be exacerbated in the future with more dam construction. Longshore drift from the Mekong River mouths is southwards towards Mui Ca Mau. As compared with the pre-dam period, monthly suspended sediment concentration decreased about $20-30 \%$ at the Vietnamese stations of Tan Chau, My Thuan and Can Tho ( $\mathrm{Lu}$ and Siew, 2006), but the impact particularly on the erosion of the eastern coast is unpredictable.

\subsection{Accretion along the Gulf of Thailand}

The strong longshore drift associated with the wave action eroding the East Sea shoreline transfers sediment to the Gulf of Thailand (MAB Vietnam, 2014). A huge amount of sediment in the East Sea is transported to the Gulf of Thailand by the Cua Lon River, then accumulates at the Cua Lon Estuary at an average rate of $70-80 \mathrm{mg} \mathrm{L}^{-1}$ (November-April) and $30 \mathrm{mg} \mathrm{L}$ (May-October). It is estimated Cua Lon River transfers about 1030000 tons $\mathrm{yr}^{-1}$ of sediment from the East Sea to the Gulf of Thailand (MAB Vietnam, 2014). As a consequence, this study shows accretion is dominant along the Gulf of Thailand (Table 4, Figs. 3-5). Especially, the three islands of Con Trong (zone 4), Con Ngoai (zone 5) and Con Moi (zone 6) were newly formed in the 1960s, 1980s, and 2000s, respectively.

Figure 6 clearly shows Con Trong (zone 4) is continuing to advance seaward to meet Con Ngoai (zone 5) at the northeastern tip and Con Moi (zone 6) on the western bank. Geographically, sediment from the Cua Lon River and from 


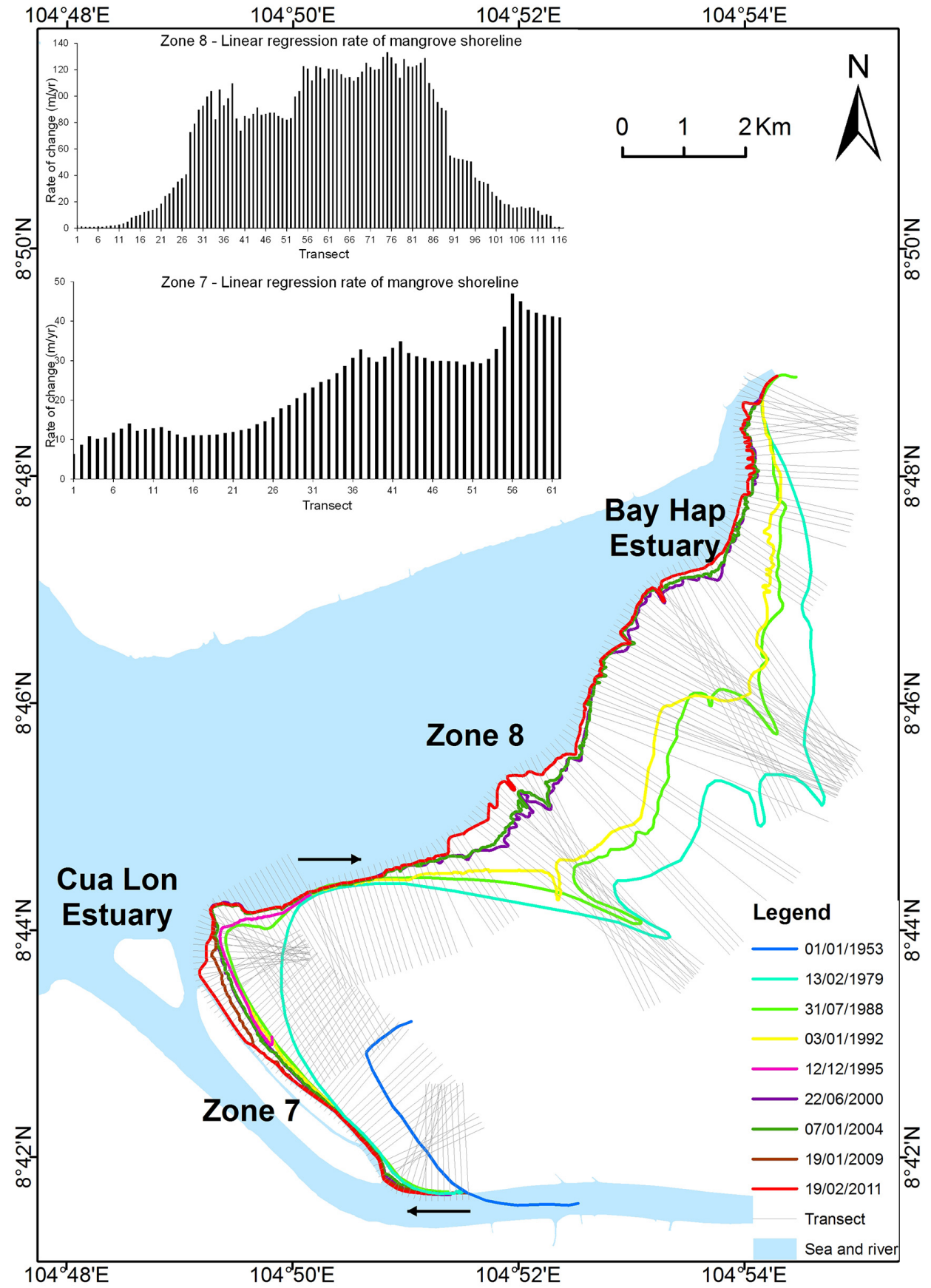

Figure 5. Mangrove shoreline change in zones 7 and 8. Mangrove shoreline 1953 is not observed in zone 8 . DSAS software generated 62 and 117 transects for zone 7 and zone 8, respectively. The arrows show the direction of transects from 1 to 62 for zone 7 and from 1 to 117 for zone 8 .

the East Sea (transported by rivers, canals and shore drift) is interpreted as the main sediment source (MAB Vietnam, 2014). Mangroves on these three newly formed islands have been growing naturally.

\subsection{Implication for mangrove management and conservation}

Sediment accretion and erosion evidently influences the ability of propagules to disperse and establish, which therefore influences the spatio-temporal changes in mangroves (Clarke et al., 2001; Sousa et al., 2007). Most of propagules were 
found to disperse over a short distance up to tens of metres (McGuinness, 1997; Breitfuss et al., 2003; Sousa et al., 2007; De Ryck et al., 2012). However, some propagules dispersed over extensive ranges, even more than $50 \mathrm{~km}$ (Clarke, 1993). In all cases, microtopography and sediment dynamics of the site colonized will determine to a great extent whether or not propagules will establish and survive their earliest stages as a growing tree. Excessive erosion will prevent the propagules from establishing or stabilizing in the soil, whereas excessive accretion might cover and suffocate the seedlings. In addition, propagule buoyancy, period of obligate dispersal, anchoring time, tides, currents, wind and even dyke removal are primary factors determining dispersal and establishment of mangroves (Clarke, 1993; McGuinness, 1997; Di Nitto et al., 2013; Van der Stocken et al., 2013). After stranding and establishment, other factors become important in determining survival including predation, interspecific competition, flooding regime, and soil physico-chemical characteristics (Clarke et al., 2001; Delgado et al., 2001; Cannicci et al., 2008; Krauss et al., 2008). As stated by Duke et al. (1998), if (an adult specimen of) a species is present, the environment must be suitable for it, but the opposite does not apply. The shoreline of Mui $\mathrm{Ca} \mathrm{Mau}$ is characterized by river alluvium and is a "soft shoreline" where the mangrove forest plays a vital important role in the erosion and accretion process of the coast (MAB Vietnam, 2008). The results show the mangrove shoreline is changing dynamically with erosion and accretion dominating along the East Sea and Gulf of Thailand, respectively.

Along the East Sea coastline, it was observed that some sections of the Ho Chi Minh road (Prime Minister, 2007, 2012) are being built about $1 \mathrm{~km}$ inland from the mangrove shoreline. If erosion persists along the East Sea, mangroves at some parts will be lost resulting in loss of their wave buffering and sheltering effect. This will threaten residential areas and infrastructure behind the mangrove, such as the Ho Chi Minh road. Similar situations are reported from Suriname, where dynamic mud banks shifting along the shore lead to mangrove destruction and eventually to road destruction (S. Naipal, personal communication, 2010). Therefore, adaptation measures combining "soft" and "hard" solutions focusing on wave reduction, facilitating accretion, and mangrove reforestation are needed. This is not only for the purpose of existing coastal protection but also long-term coastal engineering to take advantage of alluvium from the rivers in the Mekong Delta to advance the shoreline to the sea. In order to achieve success in these combined measures, the following recommendations should be considered by mangrove managers in the study area. Firstly, measures for accretion combining mangrove reforestation should be implemented seaward progressively. Secondly, infrastructure for wave reduction should be considered in short-term, simple and locally used material terms. For mangrove growth, these measures should aim to ensure the accretion rate is not too fast with too small-grained alluvium only. Thirdly, advanced techniques for mangrove reforestation and protection should be considered.

Along the Gulf of Thailand, the mangrove shoreline of zone 3, from Rach Tau to the Cua Lon Estuary, is considered an important spawning ground for valuable aquatic species. There are about 8 billion breeding shrimps generated per year in Mui Ca Mau (MAB Vietnam, 2008). From interviews, it is noted that local people usually use rakes to illegally collect breeding aquatic organisms (fish, shrimp, clam, etc.) for livelihood. In the field, we observed fingerprints of peanut worms digging in the mangrove floor. These techniques threaten the aerial root system and propagules of pioneer mangrove species, especially Avicennia spp. In addition, Ha and van Dijk (2013) stated that overexploitation is unavoidable in nearshore waters because of the limitation of alternative sources of income. Therefore, the issue of overcapacity in aquaculture and capture fisheries needs to be addressed, and national policy is required to move a significant proportion of coastal livelihoods to non-marine livelihood alternatives (IUCN, 2012). In addition, public awareness should be raised. Mangroves on the three newly formed islands of Con Trong (zone 4), Con Ngoai (zone 5) and Con Moi (zone 6) have been growing naturally. These can potentially be open laboratories for scientific activities on mangrove ecosystems and should be strictly protected.

However, the capacity to implement any measure is not yet present. The staff of the Mui Ca Mau National Park lacks the numbers for functional operation. In order to be able to enlarge the mangrove protection zone and to maintain the present status of the forest, more staff is needed. It could be that volunteering co-workers will step forward after awareness has risen, but still encouragement by higher authorities is necessary (Van Dam, 2010).

Furthermore, there is a need for solutions concerning the lack of interaction between the different agencies responsible for the protection of certain aspects of mangrove management. Policies, laws and regulations governing mangroves in Vietnam are incoherent, incomplete and inconsistent. Consequently, attempts to manage mangrove ecosystems are frustrated by policy, legislative and regulatory complexity, confusion, contradiction and conflict. A root cause is that administrative responsibility for mangroves and the coastal area is shared among multiple government institutions within two ministries: the Ministry of Natural Resources and Environment, which is responsible for coastal planning, land allocation, biodiversity conservation, aquatic ecosystem management and protection, and climate change; and the Ministry of Agriculture and Rural Development, which is responsible for the management of forests, terrestrial and marine protected areas, capture fisheries, aquaculture, sea dykes, storm and flood control (IUCN, 2012). Even at a local scale there is a poor communication between the monitoring, managing and exploiting authorities. The contact of these groups with provincial authorities is hardly present (Van Dam, 2010). We agree with Ha et al. (2014) stating that forest management 
in Ca Mau has become more decentralized on paper; however decentralization of management cannot be implemented because of both vertical (from central to local) and horizontal (among local) linkages. At the local level, the following measures should be considered by the public servants and officials: (i) allocation of mangroves and forestland to households for long-term use; (ii) management rights between contractors and sub-contractors; (iii) better dissemination of benefit sharing; (iv) allocating forests to different organizations; and (v) enhancement of monitoring and control mechanisms against lobbying or corruption (Ha et al., 2014).

\section{Conclusions}

The study on mangrove shoreline changes in Mui Ca Mau between 1953 and 2011 confirms that erosion and accretion, respectively, are significant along the East Sea and the Gulf of Thailand. Along $60 \mathrm{~km}$ of mangrove shoreline at the East Sea side, the mean LRR of erosion was found to be $33.24 \mathrm{~m} \mathrm{yr}^{-1}$. The accretion trend at the Gulf of Thailand side had an average rate of $40.65 \mathrm{~m} \mathrm{yr}^{-1}$.

The combination of remote sensing and GIS techniques is a helpful tool to detect mangrove shoreline movement changes over time in response to both natural and anthropogenic forces. The method should be good for application in other Mekong Delta areas where there has been erosion or where the situation is complex. Understanding the nature of changes, either natural or human, is a basic knowledge to facilitate suitable planning, management, and regulation of coastal wetland.

The results obtained from the study will aid scientists in predicting areas most at risk of erosion and/or progress of accretion in the future. Furthermore, it will facilitate the managers and decision makers to propose adaptation measures as well as to incorporate wetland management plans into plans and strategies at both provincial and national levels. Especially, it will contribute to a provincial, effective coastal zone management plan to respond to climate change and sea level rise in Ca Mau.

Acknowledgements. This study was supported by the Vlaamse Interuniversitaire Raad (VLIR) and the Mangrove Ecosystem Research Centre, Hanoi National University of Education in cooperation with Belgian Science Policy Office (BelSPO) and the Vietnamese Ministry of Science and Technology (MOST) project. We are thankful to colleagues of the Laboratory of Plant Biology and Nature Management, Vrije Universiteit Brussel, Belgium and the Center for HydroMet and Environment Consultancy, Institute of Meteorology, Hydrology and Environment, Vietnam for giving us facilities to carry out this study. The authors would like to thank Le Minh Loc (Ca Mau Forestry Department, Vietnam) and Nick Wilson (Forest Science Institute of South Vietnam) for their scientific comments. Further thank is given to Mui Ca Mau National Park for all logistics support in the field.

Edited by: B. Satyanarayana

\section{References}

Alberico, I., Amato, V., Aucelli, P. P. C., D’Argenio, B., Paola, G. Di, and Pappone, G.: Historical shoreline change of the Sele Plain (Southern Italy): The 1870-2009 time window, J. Coastal Res., 28, 1638-1647, 2012.

Ali, T. A.: New methods for positional quality assessment and change analysis of shoreline features, $\mathrm{PhD}$ thesis, Graduate program in Geodetic Science and Surveying, Ohio State University, US, 142 pp., 2003.

Appeaning Addo, K., Walkden, M., and Mills, J. P.: Detection, measurement and prediction of shoreline recession in Accra, Ghana, ISPRS J. Photogramm. Remote Sens., 63, 543-558, 2008.

Binh, T. N. K. D., Vromant, N., Hung, N. T., Hens, L., and Boon, E. K.: Land cover changes between 1968 and 2003 in Cai Nuoc, Ca Mau peninsula, Vietnam, Environment, Develop. Sustainab., 7, 519-536, 2005.

Breitfuss, M. J., Connolly, R. M., and Dale, P. E. R.: Mangrove distribution and mosquito control: transport of Avicennia marina propagules by mosquito-control runnels in southeast Queensland saltmarshes, Est. Coast. Shelf Sci., 56, 573-579, 2003.

Ca Mau Portal: Forest resource, http://www.camau.gov.vn/wps/ portal/camauportal (last access: 8 April 2014), 2014.

Cannicci, S., Burrows, D., Fratini, S., Smith III, T. J., Offenberg, J., and Dahdouh-Guebas, F.: Faunistic impact on vegetation structure and ecosystem function in mangrove forests: A review, Aquatic Bot., 89, 186-200, 2008.

Chand, P. and Acharya, P.: Shoreline change and sea level rise along coast of Bhitarkanika wildlife sanctuary, Orissa: An analytical approach of remote sensing and statistical techniques, Int. J. Geomat. Geosci., 1, 436-455, 2010.

Chen, L. C. and Rau, J. Y.: Detection of shoreline changes for tideland areas using multi-temporal satellite images, Int. J. Remote Sens., 19, 3383-3397, 1998.

Clarke, P. J.: Dispersal of grey mangrove (Avicennia marina) propagules in southeastern Australia, Aquatic Botany, 45, 195204, 1993.

Clarke, P. J., Kerrigan, R. A., and Westphal, C. J.: Dispersal potential and early growth in 14 tropical mangroves: do early life history traits correlate with patterns of adult distribution?, J. Ecol., 89, 648-659, 2001.

Cohen, M. C. L. and Lara, R. J.: Temporal changes of mangrove vegetation boundaries in Amazonia: Application of GIS and remote sensing techniques, Wetl. Ecol. Manag., 11, 223-231, 2003.

Cowart, L., Corbett, D. R., and Walsh, J. P.: Shoreline change along sheltered coastlines: Insights from the Neuse River Estuary, NC, USA, Remote Sens., 3, 1516-1534, 2011.

Coyne, M. A., Fletcher, C. H., and Richmond, B. M.: Mapping coastal erosion hazard areas in Hawaii: observation and errors, J. Coastal Res., 28, 171-184, 1999.

Crowell, M., Douglas, B. C., and Leatherman, S. P.: On forecasting future U.S. shoreline positions: a test of algorithms, J. Coastal Res., 13, 1245-1255, 1997.

Dahdouh-Guebas, F.: The use of remote sensing and GIS in the sustainable management of tropical coastal ecosystems, Environment, Develop. Sustainab., 4, 93-112, 2002.

Dahdouh-Guebas, F., Van Pottelbergh, I., Kairo, J. G., Cannicci, S., and Koedam, N.: Human-impacted mangroves in Gazi (Kenya): predicting future vegetation based on retrospective remote sens- 
ing, social surveys, and tree distribution, Mar. Ecol.-Prog. Ser., 272, 77-92, 2004.

Dahdouh-Guebas, F., Hettiarachchi, S., Sooriyarachchi, S., Lo Seen, D., Batelaan, O., Jayatissa. L. P, and Koedam, N.: Transitions in ancient inland freshwater resource management in Sri Lanka affect biota and human populations in and around coastal lagoons, Curr. Biol., 15, 579-586, 2005.

Delgado, P., Hensel, P. F., Jiménez, J. A., and Day J. W.: The importance of propagule establishment and physical factors in mangrove distributional patterns in a Costa Rican estuary, Aquatic Bot., 71, 157-178, 2001.

De Ryck, D. J. R., Robert, E. M. R., Schmitz, N., Van der Stocken, T., Di Nitto, D., Dahdouh-Guebas, F., and Koedam, N.: Size does matter, but not only size: Two alternative dispersal strategies for viviparous mangrove propagules, Aquatic Bot., 103, 66-73, 2012.

Di Nitto, D., Erftemeijer, P. L. A., van Beek, J. K. L., DahdouhGuebas, F., Higazi, L., Quisthoudt, K., Jayatissa, L. P., and Koedam, N.: Modelling drivers of mangrove propagule dispersal and restoration of abandoned shrimp farms, Biogeosciences, 10, 5095-5113, doi:10.5194/bg-10-5095-2013, 2013.

Dolan, R., Fenster, M. S., and Holme, S. J.: Temporal analysis of shoreline recession and accretion, J. Coastal Res., 7, 723-744, 1991.

Duke, N. C., Ball, M. C., and Ellison, J. C.: Factors influencing biodiversity and distributional gradients in mangroves, Glob. Ecol. Biogeogr. Lett., 7, 27-47, 1998.

Ellison, J. C. and Zouh, I.: Vulnerability to climate change of mangroves: Assessment from Cameroon, Central Africa, Biology, 1, 617-638, 2012

El-Raey, M., Frihy, O., Nasr, S., and Dewidar, K.: Vulnerability assessment of sea level rise over Port Said Governorate, Egypt, Environ. Monit. Assess., 56, 113-128, 1999.

Esteves, L. S., Williams, J. J., Nock, A., and Lymbery, G.: Quantifying shoreline changes along the Sefton coast (UK) and the implications for research-informed coastal management, J. Coastal Res., 56, 602-606, 2009.

FAO (Food and Agriculture Organization of the United Nations): Mangroves of Asia 1980-2005: Country reports, Rome, Working Paper, 137, 148 pp., 2007.

Fromard, F., Vega, C., and Proisy, C.: Half a century of dynamic coastal change affecting mangrove shorelines of French Guiana, A case study based on remote sensing data analyses and field surveys, Mar. Geol., 208, 265-280, 2004.

Genz, A. S., Fletcher, C. H., Dunn, R. A., Frazer, L. N., and Rooney, J. J.: The predictive accuracy of shoreline change rate methods and alongshore beach variation on Maui, Hawaii, J. Coastal Res., 231, 87-105, 2007.

Ghosh, T., Bhandari, G., and Hazra, S.: Assessment of landuse/ landcover dynamics and shoreline changes of Sagar island through remote sensing, The 22nd Asian Conference on Remote Sensing, Singapore, 5-9 November 2001, Vol. 2, 848-852, 2001.

Giesen, W., Wulffraat, S., Zieren, M., and Scholten, L.: Mangrove guidebook for Southeast Asia, FAO and Wetlands International, ISBN: 974-7946-85-8, 769 pp., 2006.

Gilman, E., Ellison, J. C., and Coleman, R.: Assessment of mangrove response to projected relative sea-level rise and recent historical reconstruction of shoreline position, Environ. Monit. Assess., 124, 105-130, 2007.
Giri, C., Long, J., and Tieszen, L.: Mapping and monitoring Louisiana's mangroves in the aftermath of the 2010 Gulf of Mexico oil spill, J. Coastal Res., 27, 1059-1064, 2011.

Ha, T. T. P. and van Dijk, H.: Fishery livelihoods and (non)compliance with fishery regulations: A case study in Ca Mau Province, Mekong Delta, Viet Nam, Mar. Policy, 38, 417-427, 2013.

Ha, T. T. P., van Dijk, H., and Visser, L.: Impacts of changes in mangrove forest management practices on forest accessibility and livelihood: A case study in mangrove-shrimp farming system in Ca Mau Province, Mekong Delta, Vietnam, Land Use Policy, 36, 89-101, 2014.

Hai-Hoa, N., McAlpine, C., Pullar, D., Johansen, K., and Duke, N. C.: The relationship of spatial-temporal changes in fringe mangrove extent and adjacent land-use: Case study of Kien Giang coast, Vietnam, Ocean Coast. Manage., 76, 12-22, 2013.

Hapke, C. J. and Reid, D.: National assessment of shoreline change, Part 4: Historical coastal cliff retreat along the California coast: US Geological Survey Open-file Report 2007-1133, US Geological Survey, USA, 51 pp., 2007.

Hapke, C. J., Reid, D., Richmond, B. M., Ruggiero, P., and List, J.: National assessment of shoreline change, Part 3: Historical shoreline change and associated coastal land loss along sandy shorelines of the California coast, US Geological Survey Open File Report 2006-1219, US Geological Survey, USA, 69 pp., 2006.

Hapke, C. J., Reid, D., and Richmond, B.: Rates and trends of coastal change in California and the regional behavior of the beach and cliff system, J. Coastal Res., 25, 603-615, 2009.

Hapke, C. J., Himmelstoss, Emily A., Kratzmann, M. G., List, J. H., and Thieler, E. R.: National assessment of shoreline change: historical shoreline change along the New England and MidAtlantic coasts: Atlantic, US Geological Survey Open File Report 2010-1118, US Geological Survey, USA, 57 pp., 2010.

Hashimoto, T. R.: Environmental issues and recent infrastructure development in the Mekong Delta: review, analysis and recommendations with particular reference to largescale water control projects and the development of coastal areas, Working Paper No. 4, Australian Mekong Resource Centre, University of Sydney, 70 pp., 2001.

Heumann, B. W.: Satellite remote sensing of mangrove forests: Recent advances and future opportunities, Prog. Phys. Geogr., 35, 87-108, 2011.

Honeycutt, M. G., Crowell, M., and Douglas, B. C.: Shoreline position forecasting: impact of storms, rate calculation methodologies, and temporal scales, J. Coastal Res., 17, 721-730, 2001.

Hong, P. N. and San, H. T.: Mangroves of Vietnam, IUCN, Bangkok, Thailand, 1993.

Hung, H. Q. and Tan, D. T.: Plants in Ca Mau Wetland, edited by: Quynh, N. B., and Oanh, T. T., Department of Science, Technology and Environment, Ca Mau, Vietnam, 170 pp., 1999.

IUCN (International Union for Conservation of Nature): Viet Nam national strategy and action plan (2011-2013), Mangroves for the Future, Gland, Switzerland, 32 pp., 2012.

Koedam, N. and Dahdouh-Guebas, F.: Ecological quality changes precede changes in quantity in mangrove forests, Science, ELetter 2 October 2008, 2008.

Koedam, N., Dahdouh-Guebas, F., Monbaliu, D., Merken, R., Ruyck, J. De, and Minh, V. Q.: Improvement of shrimp produc- 
tion sustainability and shrimp safety in Vietnam, Vrije Universiteit Brussel, Brussels, Belgium, BelSPO Project Report, 88 pp., 2007.

Krauss, K. W., Lovelock, C. E., McKee, K. L., López-Hoffman, L., Ewe, S. M. L., and Sousa, W. P.: Environmental drivers in mangrove establishment and early development: A review, Aquatic Bot., 89, 105-127, 2008.

Kuleli, T.: Quantitative analysis of shoreline changes at the Mediterranean Coast in Turkey, Environ. Monit. Assess., 167, 387-397, 2010.

Kuleli, T., Guneroglu, A., Karsli, F., and Dihkan, M.: Automatic detection of shoreline change on coastal Ramsar wetlands of Turkey, Ocean Eng., 38, 1141-1149, 2011.

Lin, T. H., Liu, G. R., Chen, A. J., and Kuo, T. H.: Applying satellite data for shoreline determination in tideland areas, The 22nd Asian Conference on Remote Sensing, Singapore, 5-9 November 2001, 2001.

Lisa, C., Walsh J. P., and Reide, C. D.: Analyzing estuarine shoreline change: A case study of Cedar Island, North Carolina, J. Coastal Res., 26, 817-830, 2010.

Lu, X. X. and Siew, R. Y.: Water discharge and sediment flux changes over the past decades in the Lower Mekong River: possible impacts of the Chinese dams, Hydrol. Earth Syst. Sci., 10, 181-195, doi:10.5194/hess-10-181-2006, 2006.

MAB Vietnam (Man and the Biosphere Programme): Mui Ca Mau Biosphere Reserve, Ca Mau Province, Biosphere Reserve Nomination Form to be submitted to UNESCO, 112 pp., 2008.

MAB Vietnam (Man and the Biosphere Programme): $\mathrm{Ca}$ Mau Biosphere Reserve, http://www.mabvietnam.net/Vn/ MuiCaMaubios_vn.htm\{\#\}c (last access: 8 April 2014), 2014.

Maiti, S. and Bhattacharya, A. M.: Shoreline change analysis and its application to prediction: A remote sensing and statistics based approach, Mar. Geol., 257, 11-23, 2009.

Mangham, W. and Williams, H.: GPS-based analysis of shoreline change, 1995-2005, Mad Island Marsh Preserve, Matagorda County, Texas, Texas J. Sci., 59, 61-72, 2007.

MARD (Ministry of Agriculture and Rural Development): An announcement on National Forest Status in 2012, 1736/QD-BNNTCLN, 8 pp., 2013.

Massó i Alemán, S., Bourgeois, C., Appeltans, W., Vanhoorne, B., De Hauwere, N., Stoffelen, P., Heaghebaert, A., and DahdouhGuebas, F.: The "Mangrove Reference Database and Herbarium”, Plant Ecol. Evol., 143, 225-232, 2010.

McGuinness, K. A.: Dispersal, establishment and survival of Ceriops tagal propagules in a north Australian mangrove forest, Oecologia, 109, 80-87, 1997.

McIvor, A. L., Spencer, T., Möller, I., and Spalding, M.: The response of mangrove soil surface elevation to sea level rise, Natural Coastal Protection Series: Report 3, Cambridge Coastal Research Unit Working Paper 42, Published by The Nature Conservancy and Wetlands International, 59 pp., 2013.

MONRE (Ministry of Natural Resources and Environment): Climate change, sea level rise scenarios for Vietnam, Vietnam Publishing House of Natural Resources, Environment and Maps, 96 pp., 2012.

Morton, R. A. and Miller, T. L.: National assessment of shoreline change, Part 2: Historical shoreline changes and associated coastal land loss along the US Southeast Atlantic Coast, US Geo- logical Survey Open File Report 2005-1401, US Geological Survey, USA, 35 pp., 2005.

Morton, R. A., Miller, T. L., and Moore, L. J.: National assessment of shoreline change, Part 1: Historical shoreline changes and associated coastal land loss along the U.S. Gulf of Mexico, US Geological Survey Open File Report 2004-1043, US Geological Survey, USA, 44 pp., 2004.

Natesan, U., Thulasiraman, N., Deepthi, K., and Kathiravan, K.: Shoreline change analysis of Vedaranyam coast, Tamil Nadu, India, Environ. Monit. Assess., 185, 5099-5109, 2013.

Nfotabong-Atheull, A., Din, N., and Dahdouh-Guebas, F.: Qualitative and quantitative characterization of mangrove vegetation structure and dynamics in a peri-urban setting of Douala (Cameroon): An approach using air-borne imagery, Estuar. Coast., 36, 1181-1192, 2013.

Otsu, N.: A threshold selection method from gray-level Histograms, IEEE Transactions on Systems, Man, and Cybernetics, 9, 62-66, 1979.

Prime Minister: Decision on the master plan of Ho Chi Minh road, 242/QD-TTg, 12 pp., 2007.

Prime Minister: Decision on the detail plan of Ho Chi Minh road, 194/QD-TTg, 17 pp., 2012.

Rahman, A. F., Dragoni, D., and El-Masri, B.: Response of the Sundarbans coastline to sea level rise and decreased sediment flow: A remote sensing assessment, Remote Sens. Environ., 115, 31213128, 2011.

Rebelo, L. M., Finlayson, C. M., and Nagabhatla, N.: Remote sensing and GIS for wetland inventory, mapping and change analysis, J. Environ. Manage., 90, 2144-2153, 2009.

Ross, P.: The mangrove of southern Vietnam: the impact of military use of herbicides, in: Proceedings of International Symposium on Biological and Management of Mangroves, Hololulu, 2, 695707, 1975.

Saintilan, N. and Wilton, K.: Changes in the distribution of mangroves and saltmarshes in Jervis Bay, Australia, Wetl. Ecol. Manag., 9, 409-420, 2001.

Satyanarayana, B., Koedam, N., De Smet, K., Di Nitto1, D., Bauwens, M., Jayatissa, L. P., Cannicci, S., and DahdouhGuebas, F.: Long-term mangrove forest development in Sri Lanka: early predictions evaluated against outcomes using VHR remote sensing and VHR ground-truth data, Mar. Ecol.-Prog. Ser., 443, 51-63, 2011.

Seto, K. C. and Fragkias, M.: Mangrove conversion and aquaculture development in Vietnam: A remote sensing-based approach for evaluating the Ramsar Convention on Wetlands, Global Environ. Chang., 17, 486-500, 2007.

Sesli, F. A., Karsli, F., Colkesen, I., and Akyol, N.: Monitoring the changing position of coastlines using aerial and satellite image data: an example from the eastern coast of Trabzon, Turkey, Environ. Monit. Assess., 153, 391-403, 2009.

Sezgin, M. and Sankur, B.: Survey over image thresholding techniques and quantitative performance evaluation, J. Electron. Imaging, 13, 146-165, 2004.

Sheik, M. and Chandrasekar: A shoreline change analysis along the coast between Kanyakumari and Tuticorin, India, using digital shoreline analysis system, Geo-Spat. Informat. Sci., 14, 282 293, 2011.

Solomon, S., Kruger, J., and Forbes, D.: An approach to the analysis of storm-surge and sea-level vulnerability using GIS: Suva, Fiji, 
South Pacific, in: Proceedings of the Canadian Coastal Conference, Ottawa, Canada, 21-24 May 1997, 1997.

Sousa, W. P., Kennedy, P. G., Mitchell, B. J., and Ordínez L., B. M.: Supply-side ecology in mangroves: do propagule dispersal and seedling establishment explain forest structure?, Ecol. Monogr., 77, 53-76, 2007.

Souza Filho, P. W. M., Martins, E. do S. F., and Costa, F. R.: Using mangroves as a geological indicator of coastal changes in the Bragança macrotidal flat, Brazilian Amazon: A remote sensing data approach, Ocean Coast. Manage., 49, 462-475, 2006.

Stellman, J. M., Stellman, S. D., Christian, R., Weber, T., and Tomasallo, C.: The extent and patterns of usage of Agent Orange and other herbicides in Vietnam, Nature, 422, 681-687, 2003.

Thao, P. T. P., Duan, H. D., and To, D. V.: Integrated remote sensing and GIS for calculating shoreline change in Phan Thiet coastal area, International Symposium on Geoinformatics for Spatial Infrastructure Development in Earth and Allied Sciences, Hanoi, Vietnam, 2008.

Thieler, E. R. and Danforth, W. W.: Historical shoreline mapping (II): Application of the digital shoreline mapping and analysis systems (DSMS/DSAS) to shoreline change mapping in PuertoRico, J. Coastal Res., 10, 600-620, 1994.

Thieler, E. R., Rodriguez, R. W., and Carlo, M.: Beach erosion and coastal development at Rincon, Puerto Rico, Shore Beach, 63, 18-28, 1995.

Thieler, E. R., Himmelstoss, E. A., Zichichi, J. L., and Ergul, A.: Digital Shoreline Analysis System (DSAS) version 4.0-An ArcGIS extension for calculating shoreline change, US Geological Survey Open File Report 2008-1278, US Geological Survey, USA, 2009.
Van, T. T, Wilson, N., Thanh-Tung, H., Quisthoudt, K., QuangMinh, V., Xuan-Tuan, L., Dahdouh-Guebas, F., and Koedam, N.: Changes in mangrove vegetation area and character in a war and land use change affected region of Vietnam (Mui Ca Mau) over six decades, Acta Oecol., in review, 2014.

Van Dam, T.: Potential impacts of climate change induced sea level rise on mangroves in Ca Mau, South Vietnam: Application of remote sensing techniques for assessment, M. S. thesis, Vrije Universiteit Brussel, Belgium, 95 pp., 2010.

Van der Stocken, T., De Ryck, D. J. R., Balke, T., Bouma, T. J., Dahdouh-Guebas, F., and Koedam, N.: The role of wind in hydrochorous mangrove propagule dispersal, Biogeosciences, 10, 3635-3647, doi:10.5194/bg-10-3635-2013, 2013.

Van der Wal, D., Pye, K., and Neal, A.: Long-term morphological change in the Ribble Estuary, northwest England, Science, 189, 249-266, 2002.

Vanderstraete, T., Goossens, R., and Ghabour, T. K.: The use of multi-temporal Landsat images for the change detection of the coastal zone near Hurghada, Egypt, Int. J. Remote Sens., 27, 3645-3655, 2006.

Vo, Q. T., Oppelt, N., Leinenkugel, P., and Kuenzer, C.: Remote sensing in mapping mangrove ecosystems - An Object-Based Approach, Remote Sens., 5, 183-201, 2013.

Wilton, K. and Saintilan, N.: Protocols for mangrove and saltmarsh habitat mapping, Unit Technical Report 2000/01, Coastal Wetlands Unit, Australian Catholic University, Australia, 2000.

Woodroffe, C. D.: Response of tide-dominated mangrove shorelines in Northern Australia to anticipated sea-level rise, Earth Surf. Proc. Land., 20, 65-85, 1995. 